Original Article

\title{
APOPTOSIS INDUCING EFFECT OF SILVER NANOPARTICLES SYNTHESIZED USING MAGNOLIA CHAMPACA LEAF EXTRACT ON MCF-7 CELL LINE
}

\author{
ANNA ANTONY ${ }^{1}$, NEHA SHRIVASTAV ${ }^{*}$, SIDDHARTH DUBEY ${ }^{2}$, ASHUTOSH ACHARYA ${ }^{2}$
}

${ }^{1}$ Department of Life Sciences, CHRIST (Deemed to be University), Bengaluru, Karnataka, India 560029, ${ }^{2}$ Cellkraft Biotech Pvt. Ltd, Hebbal, Bengaluru, Karnataka, India 560024

Email: niashrivastav@gmail.com

Received: 26 Jan 2021, Revised and Accepted: 21 Mar 2021

\begin{abstract}
Objective: To synthesize silver nanoparticle (AgNP) using the ethanolic leaf extract of Magnolia champaca (MC-AgNP) and to evaluate its cytotoxicity and apoptotic activity in MCF-7 cell line, and to analyse active Caspase-3 expression in inducing apoptosis.

Methods: AgNP was green synthesized using ethanolic leaf extract of MC. Shape and size were analysed by SEM and particle size analyser. Cytotoxicity was tested to find $\mathrm{IC}_{50}$ value. Apoptosis was explored by mitochondrial membrane potential $(\Delta \Psi \mathrm{m})$ assay and active Caspase- 3
\end{abstract} expression study using flow cytometry.

Results: AgNP synthesized was observed to be in spherical shape through SEM micrograph with $164.6 \mathrm{~nm}$ in size. IC 50 value of $15.90 \mu \mathrm{g} / \mathrm{ml}$ was obtained after $24 \mathrm{~h}$ of drug treatment. Changes in $\Delta \Psi \mathrm{m}$ and positive active Caspase-3 protein expression were observed.

Conclusion: The present results suggest that MC-AgNP has potential anticancer property and also induced cell death via apoptosis through caspase dependent pathway in MCF-7 cells.

Keywords: Magnolia champaca, Green-synthesis, Anticancer, Apoptosis, Caspase-3

(c) 2021 The Authors. Published by Innovare Academic Sciences Pvt Ltd. This is an open access article under the CC BY license (https://creativecommons.org/licenses/by/4.0/) DOI: https://dx.doi.org/10.22159/ijcpr.2021v13i3.42083 Journal homepage: https://innovareacademics.in/journals/index.php/ijcpr

\section{INTRODUCTION}

Cancer is one among the leading cause of human death across the world. Breast cancer is the most diagnosed of all type cancer with about 1 million new cases per year and accounts for about $23 \%$ of total cancer cases and $14 \%$ of cancer deaths. Natural products mostly plant products have been used in cancer treatment for more than 3,500 $\mathrm{y}$. These play a key role in modern medicine as a natural source of cancer drugs with least side effects [1-3]. Plant products and their derivatives are dependent upon widely as effective chemotherapeutic drugs. Around $50 \%$ of the small molecules sanctioned for cancer chemotherapy in western medication throughout the most recent $70 \mathrm{y}$ are either natural products that are unmodified structurally or synthetic derivatives of those products $[4,5]$.

Magnolia champaca (MC) is a member of family Magnoliaceae that is famous for its fragranced flowers. It is also known as Swarna Champa and originated in the temperate Himalayan region and distributed throughout the Indian, Chinese and Indonesian lands. MC is a tall woody tree species, which has high economic value for medicinal and fragrance products such as essential oils, cosmetics and perfumes [6-8]. Various parts of the tree including flower, seed, bark and leaves have been reported to possess various pharmacological activities such as anti-microbial, anti-oxidant, antidiabetic, anti-cancerous, anti-inflammatory, leishmanicidal, anthelmintic, anti-ulcer and anti-uretic etc [9-15].

Green synthesis of nanoparticles ensures exclusion in the usage of the substances which are detrimental to human health and hazardous to environment. Nanoparticles ranges from 1 to $100 \mathrm{~nm}$ and are synthesized in variable shapes, sizes and chemical compositions, with potential properties for human benefits. Metal nanoparticles are essential tools in drug delivery due to special properties of bulk material formation and production of quantum effects due to their smaller size [16-18]. In the present study, cytotoxicity of silver nanoparticle synthesised from the ethanolic extract of leaves of Magnolia champaca (MC-AgNP) was investigated on human breast cancer cell line (MCF-7). Apoptosis-inducing effect and active caspase- 3 expression of MC-AgNP was determined by flow cytometry to confirm the anticancer mechanism.

\section{MATERIALS AND METHODS}

\section{Chemicals}

Dulbecco's Modified Eagle Medium with High Glucose (DMEM-HG), Foetal Bovine Serum (FBS), Dulbecco's Phosphate Buffered Saline (DPBS), trypsin-EDTA solution, MTT reagent, dimethyl sulfoxide, paraformaldehyde solution, Bovine Serum Albumin (BSA), triton-X 100 were all purchased from HiMedia, India. Flow cytometry mitochondrial membrane potential detection kit $\mathrm{BD}^{\mathrm{TM}}$ MitoScreen (BD, Biosciences, catalog no. 551302) and FITC rabbit anti-human active caspase-3 IgG Antibody (BD Biosciences, catalog no. 559341) was bought from BD Biosciences, USA.

\section{Plant material and preparation of extract}

MC leaves were collected from a mature tree growing at the main campus of CHRIST (Deemed to be University), Bangalore, India. The leaves were identified and authenticated by Foundation for Revitalization of Local Health Traditions (FRLHT), Bangalore. The leaves were cut into small pieces, washed with distilled water, dried and powdered. The sample was extracted using Soxhlet apparatus with ethanol as the extracting solvent and $60 \mathrm{~g}$ powdered leaf. The extract was filtered using Whatman filter paper no. 1, weighed and stored at $4{ }^{\circ} \mathrm{C}$.

\section{Phytochemical analysis}

Qualitative phytochemical analysis of the ethanolic extract of MC was performed following Liebermann's test for glycosides, Salkowski test for terpenoids and steroids, Wagner's test for Alkaloids, Ferric Chloride test for tannins, phenols and flavonoids [19-23].

\section{Green synthesis of silver nanoparticles}

MC leaf extract of $5 \mathrm{mg} / \mathrm{ml}$ was added to $50 \mathrm{ml}$ of $20 \mathrm{mmol}$ aqueous solution of $\mathrm{AgNO}_{3}$. It was kept covered with an aluminium foil and was stored in dark at room temperature for $72 \mathrm{~h}$. The silver nanoparticle was filtered with a microfilter of $0.2 \mu$, dried and stored in a vial covered with aluminium foil at $4{ }^{\circ} \mathrm{C}$. 


\section{Characterization and size analysis of nanoparticles}

About $25 \mu \mathrm{l}$ of the MC-AgNP synthesized was loaded on a copper stub (1 $\mathrm{mm}$ diameter) attached to a double-sided carbon material, provided for SEM analysis. SEM observation was performed on a JEOL JSM-6360 electron microscope, with an accelerating voltage of $18 \mathrm{kV}$ and the working distance was adjusted to around $18 \mathrm{~mm}$. The particle size was established by particle size analyzer by Horiba scientific SZ-100. $5 \mathrm{mg} / \mathrm{ml}$ stock solution of nanoparticle was prepared in distilled water and sonicated for $15 \mathrm{~min}$ at $40 \mathrm{kHz}$ using a bath type sonicator (GT-Sonic Model: VGT-1613GTD). It was diluted at 10:1000 with distilled water and analyzed.

\section{Cell culture}

MCF-7 (Michigan Cancer Foundation-7) cell line was obtained from NCCS Pune and matched with ATCC STR profile. The cells were maintained in Dulbecco's Modified Eagle Medium with High Glucose (DMEM-HG) supplemented with 10\% Foetal Bovine Serum (FBS) and $2 \%$ pencillin-strepmycin. The cells were incubated at $37{ }^{\circ} \mathrm{C}$ and $5 \% \mathrm{CO}_{2}$ atmosphere.

\section{Cytotoxicity assay by MTT assay}

MCF-7 cells were plated to 96 well microtitre plate and the count was adjusted to 10,000 cells/well, using DMEM HG medium. To each well, $200 \mu \mathrm{l}$ of the cell suspension was added and the plate was incubated for $24 \mathrm{~h}$ at $37^{\circ} \mathrm{C}$ and $5 \% \mathrm{CO}_{2}$ atmosphere. The cells were treated with $200 \mu \mathrm{l}$ of different concentrations $(25,12.5,6.25,3.12$ and $1.56 \mu \mathrm{g} / \mathrm{ml})$ of MC-AgNP for $24 \mathrm{~h}$ followed by addition of $10 \%$ MTT reagent to get a final concentration of $0.5 \mathrm{mg} / \mathrm{ml}$ and was incubated for $3 \mathrm{~h}$ at $37^{\circ} \mathrm{C}$. The culture medium was removed completely without disturbing the crystals formed. Then $100 \mu \mathrm{l}$ of solubilisation solution (DMSO) was added to the wells and the plate was gently shaken in a gyratory shaker to solubilize the formed formazan. The absorbance was measured using a microplate reader at a wavelength of $570 \mathrm{~nm}$ and at $630 \mathrm{~nm}$. The percentage growth inhibition was calculated and concentration of MC-AgNP needed to inhibit cell growth by $50 \%\left(\mathrm{IC}_{50}\right)$ was obtained from the dose-response curve for MCF-7 cell line [24]. The experiment was performed in duplicates and the results were expressed as mean \pm standard error. Data is statistically analysed by one way ANOVA where means not sharing a common single letter found to be significantly different at $p \leq 0.05$.

Apoptosis study by mitochondrial membrane potential $(\Delta \Psi \mathrm{m})$ assay

Flow cytometry was used in apoptotic study ( $\mathrm{BD}^{\mathrm{TM}}$ MitoScreen Kit) according to the instructions of the manufacturer. MCF-7 cells at a density of $3 \times 10^{5}$ cells $/ 2 \mathrm{ml}$ were cultured in a 6 -well plate followed by incubation in $\mathrm{CO}_{2}$ incubator overnight at $37{ }^{\circ} \mathrm{C}$ for $24 \mathrm{~h}$. The cells

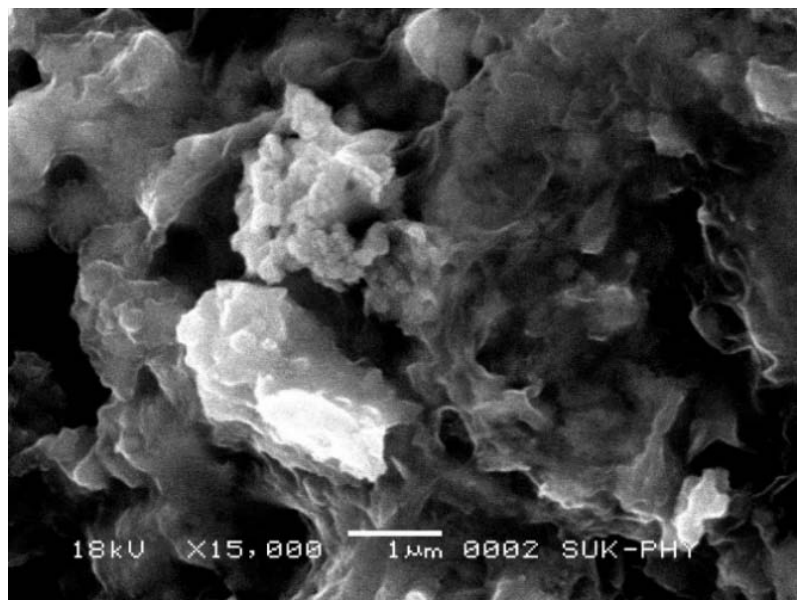

A were treated with $\left(\mathrm{IC}_{25}\right)$ of MC-AgNP, Cisplatin $(80 \mu \mathrm{g} / \mathrm{ml})$ as the positive control and one of the wells was left untreated to be used as the negative control. The cells undergone trypsin treatment with $200 \mu \mathrm{l}$ of trypsin-EDTA solution after $24 \mathrm{~h}$ of incubation. All the cells were harvested and centrifuged for $5 \mathrm{~min}$ at $300 \times \mathrm{g}\left(25^{\circ} \mathrm{C}\right)$. After decanting the supernatant, pellet was re-suspended in PBS to which about $0.5 \mathrm{ml}$ of freshly prepared JC- 1 working solution was added followed by incubation for $15 \mathrm{~min}$ at $37{ }^{\circ} \mathrm{C}$ in a $\mathrm{CO}_{2}$ incubator. The cells were washed twice with $1 \mathrm{X}$ assay buffer, re-suspended and centrifuged at $400 \times \mathrm{g}$ for $5 \mathrm{~min}$. The sample was analysed by Cytomics FC500 flow cytometer (Beckman Coulter, USA) after resuspension of the cell pellet in $0.5 \mathrm{ml}$ of $1 \mathrm{X}$ assay buffer.

\section{Active caspase-3 expression study}

A 6-well plate was used for seeding MCF-7 cells at a density of $3 \mathrm{x}$ $10^{5}$ cells $/ 2 \mathrm{ml}$. And the cells were treated with $\left(\mathrm{IC}_{25}\right)$ of MC-AgNPs (experimental test compound), after $24 \mathrm{~h}$ of seeding. MCF-7 cells were treated with Cisplatin that served as the positive control while the untreated cells served as the negative control. The cells were provided with trypsin treatment after incubation of $24 \mathrm{~h}$ followed by centrifugation at $300 \times \mathrm{g}$ at $25{ }^{\circ} \mathrm{C}$ for $5 \mathrm{~min}$ and the obtained pellet was re-suspended in PBS. This was followed by the addition of 0.5 $\mathrm{ml}$ of $2 \%$ paraformaldehyde solution and incubation for $20 \mathrm{~min}$. The cells were then washed with $0.5 \%$ BSA in $1 \mathrm{X}$ PBS. Triton-X 100 $(0.1 \%)$ in $0.5 \%$ BSA solution was added to the cells. After $10 \mathrm{~min}$ incubation, it was washed twice with $0.5 \%$ BSA in $1 \mathrm{X}$ PBS. Then $0.5 \%$ BSA in 1X PBS and $20 \mu \mathrm{l}$ FITC rabbit anti-active caspase- 3 IgG was added according to manufacturer's instructions. It was mixed thoroughly by pipetting and incubated for $30 \mathrm{~min}$ in the dark at room temperature $\left(25^{\circ} \mathrm{C}\right) .0 .5 \mathrm{ml}$ of PBS was added after washing the cells, mixed thoroughly and analysed using Cytomics FC500 flow cytometer (Beckman Coulter, USA).

\section{RESULTS AND DISCUSSION}

Preliminary phytochemical analysis of MC leaf extract showed positive for glycosides, alkaloids, flavonoids, tannins, phenols, steroids and terpenoids. Silver nanoparticles were synthesised from ethanolic extract of MC leaf using silver nitrate. The colour change from green to brownish-yellow denoted the successful formation of AgNP after $72 \mathrm{~h}$ incubation in dark at room temperature. The MCAgNPs were observed to be sticky. Fig. 1 shows SEM micrograph of AgNP aggregates. The SEM images showed the nanoparticles of various shapes, most of which were spherical. A mean size distribution of $164.6 \mathrm{~nm}$ was recorded by Particle size analyser as shown in fig. 2. Silver nanoparticle possess unique physical, chemical, biological and physicochemical properties such as chemical stability, high thermal and electrical conductivity etc. which makes it is applicable in medicines [25].

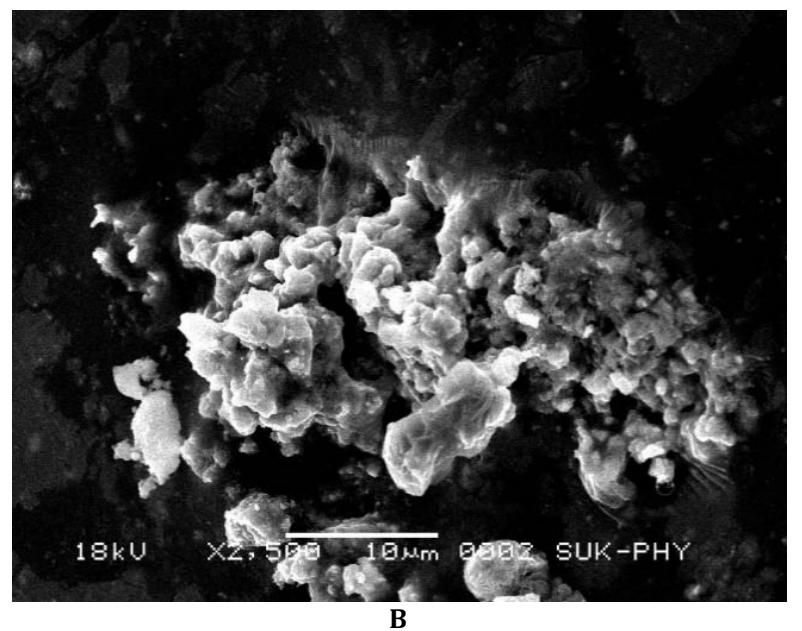

Fig. 1: Scanning tunnel electron microscope images of MC-AgNP leaf extract A) 15000X magnification and B) 2500X magnification, captured with JEOL JSM-6360 electron microscope 


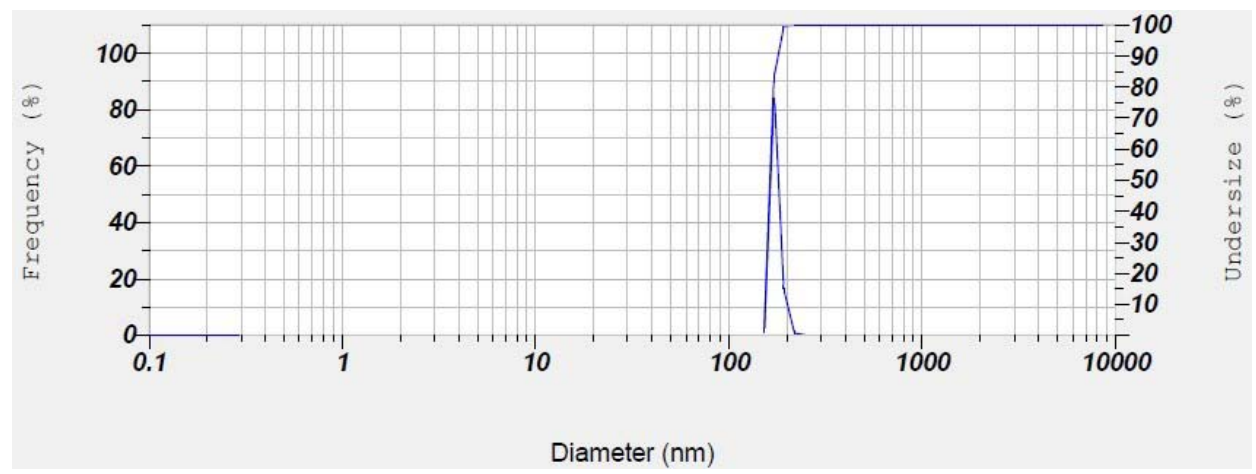

Fig. 2: Particle size distribution graph of MC-AgNP recorded by particle size analyzer (Horiba scientific SZ-100)

Anti-proliferative activity of MC-AgNPs on MCF-7 cell line was evaluated using MTT assay. MTT acts as a substrate which is reduced by mitochondrial dehydrogenase enzyme to form DMSO soluble formazan crystals [26]. MTT assay was performed for testing cytotoxicity by treating different concentration of the MC-AgNPs (3.125, 6.25, 12.5, 25 and $50 \mu \mathrm{g} / \mathrm{ml}$ ) on MCF-7 cell line (fig. 3). Based on the IC $\mathrm{C}_{50}$ value of MC-AgNPs that was observed to be $15.90 \mu \mathrm{g} / \mathrm{ml}$ for $24 \mathrm{~h}$, it could be concluded that the drug had an inhibitory effect on the growth of MCF-7 cells.

Apoptosis plays a critical role in immune response development, homeostatic control of tissue integrity and tumour regression where many morphological and biochemical changes occur in the cell, following specific signals [27]. Significantly, the events taking place in mitochondria during apoptosis is the loss or collapse of mitochondrial membrane potential $(\Delta \Psi \mathrm{m})$ [28]. The ability of MCAgNPs to induce apoptosis on MCF-7 cell was studied by JC-1 uptake into mitochondria that can be used to detect change in $\Delta \Psi \mathrm{m}$. Polarization of $\Delta \Psi \mathrm{m}$ of normal, healthy mitochondria allows itself to take up the dye in aggregated form to give red fluorescence $[29,30]$. As shown in table 1, Cisplatin (positive control) at a concentration of $80 \mu \mathrm{g} / \mathrm{ml}$ caused $32.5 \%$ apoptotic cell death and the MC-AgNPs (test drug) at $\mathrm{IC}_{25}$ caused $77.1 \%$ apoptotic cell death, whereas in untreated cells, only $3.94 \%$ induction of cell death was observed via apoptosis. JC-1 green fluorescence was collected in the FL1 detector with $525 \mathrm{~nm}$ band pass filter while red fluorescence was collected in the FL3 detector using $620 \mathrm{~nm}$ band pass filter (fig. 4).

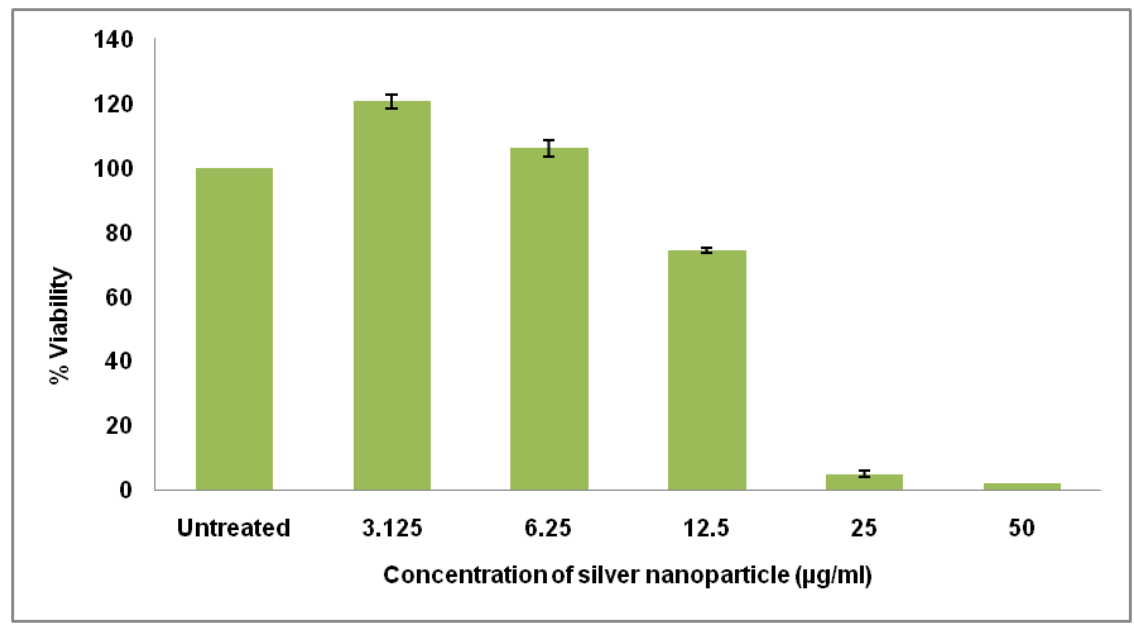

Fig. 3: Inhibition of MCF-7 cell growth by silver nanoparticle synthesised from Magnolia champaca leaf extract

Table 1: The values of apoptosis study by mitochondrial membrane potential assay through JC-1 staining using flow cytometry in MCF-7 cell line

\begin{tabular}{llll}
\hline & $\begin{array}{l}\text { Geometric mean fluorescence intensity (MFI) of JC-1 red } \\
\text { fluorescence (FL3-A parameter) }\end{array}$ & Percentage of cells \\
\cline { 2 - 3 } & 46637 & Healthy \\
\hline Untreated & 23660 & 96.0 & 37.4 \\
Cisplatin & 2819 & 21.3 & 32.94 \\
MC-AgNP & & 77.1 \\
\hline
\end{tabular}

Caspases are key protease that gets activated in both pathways of apoptosis [31]. Of all the caspases, Caspase-3 is the most important in the induction of apoptosis as it cleaves majority of caspase substrates [3,27]. An increase in the active caspase-3 positive cell population was observed in MCF-7 cells treated with the test sample MC-AgNP and positive control (Cisplatin) as compared to the untreated cells from $7.21 \%$ positive caspase- 3 cells in the untreated to $66.7 \%$ in Cisplatin treated cells and $13.7 \%$ in the MC-AgNP treated cells (table 2). Enzyme assay showed about 7\% increase in the active caspase-3 positive cell population in the cells treated with the MC-AgNP as compared to the untreated cells (fig. 5). Therefore, it was found that in MCF-7 cells induction of apoptosis was through caspase dependent pathway that contributed to its anti-cancerous property. 


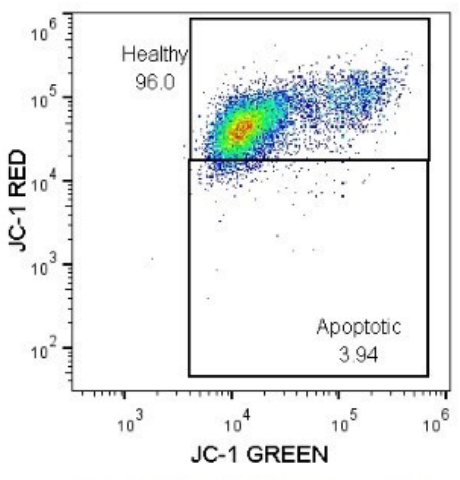

MitoMPJC-1 MCF-704Untreated 00000638 326. LMD 9590

A

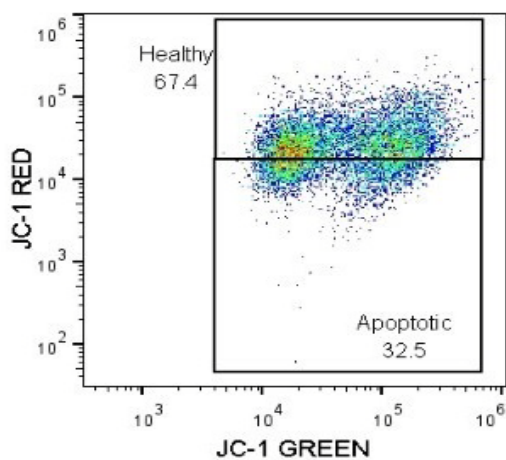

MitoMPJC-1 MCF-705Cisplatin 00000639 327.LMD Cells
9646

B

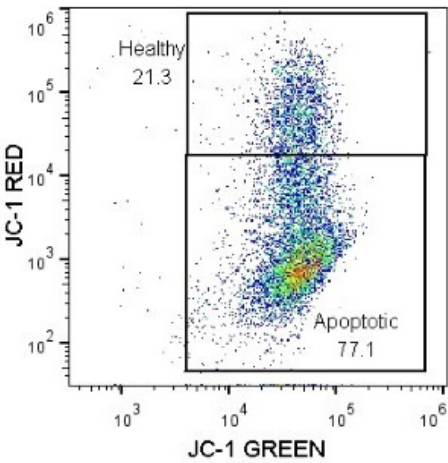

MitoMPJC-1 MCF-706AgNP 00000686 374.LMD Cells

C

Fig. 4: The plot showing the green versus red fluorescence of JC-1 A) Untreated MCF-7 cells, B) Cisplatin treated MCF-7 cells and C) AgNP treated MCF-7 cells in apoptotic study by mitochondrial membrane potential assay using Flow cytometry

Table 2: The values of flow cytometry detection of activated caspase-3 in MCF-7 cell line

\begin{tabular}{llll}
\hline & Geometric mean fluorescence intensity (MFI) of FITC Caspase- & Percentage of cells \\
\cline { 3 - 3 } & 3 (FL1-A parameter) & Caspase-3 negative \\
\hline Untreated & 613 & 92.8 \\
Cisplatin & 1709 & 33.3 \\
MC-AgNP & 623 & 86.3 \\
\hline
\end{tabular}

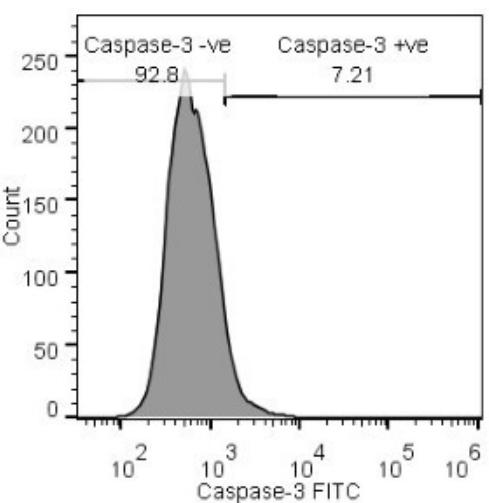

Caspase-3MCF-7 01Untreated 00000690 378.LMD Cells

A

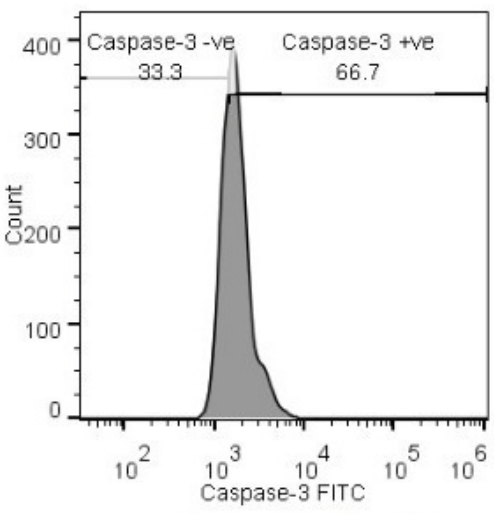

Caspase-3MCF-7 02Cisplatin 00000667 355.LMD Cells 7894

B

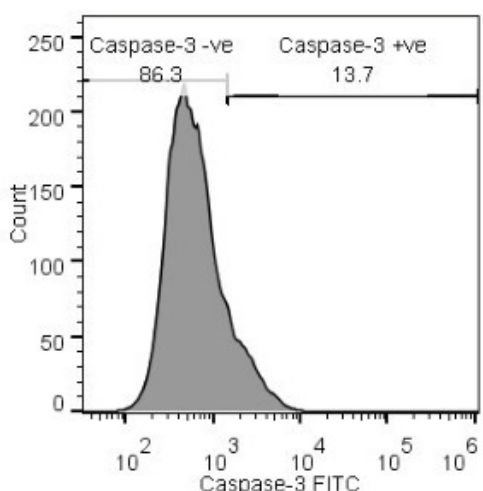

Caspase-3MCF-7 03AgNP 00000691 379.LMD Cells 8871

C

Fig. 5: The histogram plots showing the expression of active caspase-3 in x-axis versus count A) Untreated MCF-7 cells, B) Cisplatin treated MCF-7 cells and C) AgNP treated MCF-7 cells in Caspase 3 study using Flow cytometry

\section{CONCLUSION}

From the present study, it can be concluded that the MC-AgNPs can potentially induce cell death by inhibiting cell proliferation and by activating caspase dependent apoptotic pathway in MCF-7 cells. This was the first study assessing the apoptosis induction properties of silver nanoparticle synthesised from ethanolic extract of MC leaves on MCF-7 cell line. Advanced studies are crucial to interpret the appropriate mechanism by which MC-AgNP induces apoptosis.

\section{ACKNOWLEDGMENT}

The authors are grateful to Cellkraft Biotech Pvt. Ltd. and CHRIST (Deemed to be University), Bangalore, Karnataka, for providing an opportunity and good facility for the completion of the project successfully.

\section{FUNDING}

Nil

\section{AUTHORS CONTRIBUTIONS}

All authors have contributed equally.

\section{CONFLICT OF INTERESTS}

Declared none

\section{REFERENCES}

1. Yeh Y, Huang J, Kuo P, Chen C. Bioactive constituents from Michelia champaca. Nat Prod Commun 2011;6:1251-2.

2. Comșa S, Cimpean AM, Raica M. The story of MCF-7 breast cancer cell line: $40 \mathrm{y}$ of experience in research. Anticancer Res 2015;35:3147-54.

3. Jamalzadeh L, Ghafoori H, Aghamaali M, Sariri R. Induction of apoptosis in human breast cancer MCF-7 cells by a semisynthetic derivative of artemisinin: a caspase-related mechanism. Iran J Biotechnol 2017;15:157-65. 
4. Newman DJ, Cragg GM. Natural products as sources of new drugs from 1981 to 2014. J Nat Prod 2016;79:629-61.

5. Ren Y, Blanco E, Fuchs JR, Soejarto DD, Burdette JE, Swanson S, et al. Potential anticancer agents characterized from selected tropical plants. J Nat Prod 2019;82:657-79.

6. Rout PK, Naik S, Rao YR. Liquid $\mathrm{CO}_{2}$ extraction of flowers and fractionation of floral concrete of Michelia champaca linn. J Supercrit Fluids 2011;56:249-52.

7. Fernando MTR, Jayasuriya G, Walck JL, Wijetunga ASTB. Identifying dormancy class and storage behaviour of champak (Magnolia champaca) seeds, an important tropical timber tree. J Nat Sci Found 2013;41:141-6.

8. Sinha R, Varma R. Michelia champaca L. (Swarna Champa): a review. Int J Enhanc Res Sci Technol Eng 2016;5:78-82.

9. Khan MR, Kihara M, Omoloso A. Antimicrobial activity of Michelia champaca. Fitoterapia 2002;73:744-8.

10. Hasan SMR, Hossain MM, Akter R, Jamila M, Mazumder EH, Rahman S. DPPH free radical scavenging activity of some Bangladeshi medicinal plants. J Med Plant Res 2009;3:875-9.

11. Jarald EE, Joshi SB, Jain DC. Antidiabetic activity of flower buds of Michelia champaca linn. Indian J Pharmacol 2008;40:256-60.

12. Hoffmann JJ, Torrance SJ, Wiedhopf RM, Cole JR. Cytotoxic agents from Michelia champaca and Talauma ovata: parthenolide and costunolide. J Pharma Sci 1977;66:883-4.

13. Vimala R, Nagarajan S, Alam M, Susan T, Joy S. Antiinflammatory and antipyretic activity of Michelia champaca linn. (White variety), Ixora brachiata Roxb. and Rhynchosia cana (Wild.) D. C. flower extract. Indian J Exp Biol 1997;35:1310-4.

14. Takahashi M, Fuchino H, Satake M, Agatsuma Y, Sekita S. In vitro screening of leishmanicidal activity in Myanmar timber extracts. Biol Pharm Bull 2004;27:921-5.

15. Ahmed H, Saxena V, Mishra A, Gupta R. Diuretic activity of aqueous extracts of Michelia champaca L. leaves and stem bark in rats. Pharmacologyonline 2011;2:568-74.

16. Armendariz V, Herrera I, Peralta Videa JR, Jose Yacaman M, Troiani H, Santiago P, et al. Size controlled gold nanoparticle formation by Avena sativa biomass: use of plants in nanobiotechnology. J Nanoparticles Res 2004;6:377-82.

17. Bhumkar DR, Joshi HM, Sastry M, Pokharkar VB. Chitosan reduced gold nanoparticles as novel carriers for transmucosal delivery of insulin. Pharm Res 2007;24:1415-26.

18. Parimi U, Amperayani KR. Green synthesis of plant mediated silver nano particles and evaluation of their antimicrobial activities. Am J PharmTech Res 2014;4:673-9.
19. Ajiboye BO, Ibukun EO, Edobor G, Ojo AO, Onikanni SA. Qualitative and quantitative analysis of phytochemicals in Senecio biafrae leaf. Int J Pharm Sci Invent 2013;1:428-32.

20. Visweswari G, Christopher R, Rajendra W. Phytochemical screening of active secondary metabolites present in Withania somnifera root: role in traditional medicine. Int J Pharm Sci Res 2013;4:2770-6.

21. Ruwali P, Ambwani TK, Gautam P, Thapliyal A. Qualitative and quantitative phytochemical analysis of Artemisia indica willd. J Chem Pharm Res 2015;7:942-9.

22. Vijayanand S, Thomas A. Screening of Michelia champaca and Muntingia calabura extracts for potential bioactives. Int J Pharm Sci Res 2016;7:266-73.

23. Gul R, Jan SU, Faridullah S, Sherani S, Jahan N. Preliminary phytochemical screening, quantitative analysis of alkaloids and antioxidant activity of crude plant extracts from Ephedra intermedia indigenous to Balochistan. Sci World J 2017:1-7. https://doi.org/10.1155/2017/5873648

24. Bahuguna A, Khan I, Bajpai V, Kang S. MTT assay to evaluate the cytotoxic potential of a drug. Bangladesh J Pharmacol 2017;12:115-8.

25. Tran QA, Nguyen VQ, Le A. Silver nanoparticles: synthesis, properties, toxicology, applications and perspectives. Adv Nat Sci Nanosci 2013;4:1-20.

26. Mosmann T. Rapid colorimetric assay for cellular growth and survival: application to proliferation and cytotoxicity assays. J Immunol Methods 1983;65:55-63.

27. Riccardi C, Nicoletti I. Analysis of apoptosis by propidium iodide staining and flow cytometry. Nat Protoc 2006;1:145861.

28. Green DR, Reed JC. Mitochondria and apoptosis. Science 1998;281:1309-12.

29. Salvioli S, Ardizzoni A, Franceschi C, Cossarizza A. JC-1, but not DiOC6 or rhodamine 123 , is a reliable fluorescent probe to assess $\Delta \psi$ changes in intact cells: implications for studies on mitochondrial functionality during apoptosis. FEBS Lett 1997;411:77-82.

30. Salvioli S, Dobrucki J, Moretti L, Troiano L, Fernandez MG, Pinti $\mathrm{M}$, et al. Mitochondrial heterogeneity during staurosporineinduced apoptosis in HL60 cells: analysis at the single cell and single organelle level. Cytometry 2000;40:189-97.

31. Luo J, Hu Y, Kong W, Yang M. Evaluation and structure-activity relationship analysis of a new series of arylnaphthalene lignans as potential anti-tumor agents. PLoS One 2014;9:1-10. 